\title{
Mapping the Intellectual Structure of Entrepreneurship Research: revisiting the invisible college
}

\author{
A Estrutura Intelectual da Pesquisa sobre Empreendedorismo: \\ visita à escola invisivel
}

\section{La Estructura Intelectual de la Investigación sobre Emprendimiento: visita al colegio invisible}

\author{
Héctor Montiel Campos ${ }^{1}$ \\ Francesc Solé Parellada ${ }^{2}$ \\ Yarissa Palma ${ }^{3}$
}

Recebido em 06 de maio de 2011 / Aprovado em 30 de janeiro de 2012

Editor Responsável: João Maurício Gama Boaventura, Dr.

Processo de Avaliação: Double Blind Review

\begin{abstract}
Along with entrepreneurship's continuing emergence among the management sciences, there is an ongoing debate about what the field is - or should be. In this regard, to have a better understanding of the development of this research field, it is useful to understand the scientific structure. This study uses bibliometric techniques and cluster analyses to present an empirically grounded picture of the entrepreneurship research. This research analyzes the 1,112 full-length papers published in the FER Proceedings between 1981 and 2009, and the 378 articles published in the Journal of Business Venturing between 2000 and 2010. Both forums
\end{abstract}

are considered representative in the exchange of entrepreneurial thought. The results indicate that entrepreneurship research published in these forums is characterized by varied themes that are not necessarily connected. Rather, they reflect the disciplinary training and lens of their authors; and considerable dynamism and change in key research themes over time. Hopefully, the results presented here provide abundant opportunities for identifying insightful, influential, and creative research topics in the entrepreneurship field.

Key words: Entrepreneurship. Research. Forum. Invisible college.

1. Doutor em Administração pela Universidad Politécnica de Catalunya, Barcelona, Espanha. Professor da Universidad Popular Autónoma del Estado de Puebla, México. [hector.montiel@upaep.mx]

2. Doutor em Engenharia Industrial e Professor na Universidad Politécnica de Catalunya, Barcelona, Espanha. [francesc.sole@upc.edu]

3. Doutora em Engenharia de Projetos pela Universidad Politécnica de Catalunya, Barcelona, Espanha. Professora na Universidad Tecnológica de Panamá. [yarissa.palma@utp.ac.pa]

Endereço dos autores: C/ Jordi Girona 29. Edific Nexus II Planta 0A, 08034. Barcelona, Espanha 


\section{RESUMO}

O surgimento da disciplina sobre empreendedorismo em ciências de gestão gera um contínuo debate em seu âmbito. Consequentemente, para ter uma compreensão melhor do desenvolvimento dessa área de pesquisa, é útil conhecer sua estrutura científica. Esta pesquisa usa técnicas de bibliometria e análise de grupos para apresentar um panorama da pesquisa nessa disciplina. São analisados os 1.112 artigos publicados nas atas do FER, entre 1981 e 2009, bem como os 378 artigos publicados no Journal of Business Venturing, entre 2000 e 2010. Ambos os fóruns são considerados representativos no intercâmbio do pensamento sobre empreendedorismo. Os resultados mostram que a pesquisa sobre empreendedorismo publicada nesses fóruns é caracterizada por diversos temas que não estão necessariamente conectados. Similarmente, os resultados mostram a mudança dos temas ao longo do tempo.

Palavras-chave: Empreendedorismo. Pesquisa. Fórum. Escola invisível.

\section{RESUMEN}

El surgimiento de la disciplina sobre emprendimiento en las ciencias administrativas, trae consigo un continuo debate sobre su ámbito. En este sentido, para tener una mejor comprensión del desarrollo de este campo de investigación, es útil conocer su estructura científica. Esta investigación usa técnicas bibliométricas y análisis de grupos para presentar un panorama de la investigación en esta disciplina. Se analizan los 1,112 artículos publicados entre 1981 y 2009 en las actas del FER, así como los 378 artículos publicados por el Journal of Business Venturing entre 2000 y 2010. Ambos foros se consideran representativos en el intercambio del pensamiento sobre emprendimiento. Los resultados muestran que la investigación sobre emprendimiento publicada en estos foros se caracteriza por varios temas que no necesariamente están conectados; sin embargo, esto refleja la experiencia y postura de los autores. De igual forma, los resultados muestran el cambio de temas a través del tiempo.
Palabras claves: Emprendimiento. Investigación. Foro. Colegio invisible.

\section{INTRODUCTION}

Entrepreneurship is a relatively new field of research that has gained significant interest beyond the usual areas of management studies during the last few decades. In the 1970s, 1980s and 1990s, people experienced huge structural changes in society worldwide, for example oil crises, economic recessions, technical progress, an increasing internationalization of economics, and far-reaching political changes emphasizing stronger market-oriented ideologies. These changes created a level of uncertainty and disequilibrium that constituted a breeding ground for innovation and entrepreneurship. It was in this context that the interest in entrepreneurship research grew. Thus, the field of entrepreneurship, as a disciplinary research field, is not more than 25 years old, but has developed substantially over that short period of time (CORNELIUS; LANDSTRÖM; PERSSON, 2006).

Research on entrepreneurship has been characterized frequently as diverse, fragmented, and still being in ferment (BUSENITZ et al., 2003). There is no widely accepted categorization of different streams of entrepreneurship research, and it is not even clear that distinct streams exist. This lack of clear research trajectories risks inhibiting the growth of entrepreneurship as a scholarly endeavor. As the volume of entrepreneurship research continues to grow, it is useful to pause and evaluate existing entrepreneurship research to learn whether it has kept pace with the development of the entrepreneurship paradigm.

This study addresses these gaps in our understanding of the field by mapping the structure of entrepreneurship literature, and examining highly cited references in contemporary entrepreneurship research. The data set consists of all articles with entrepreneurship-related content published by the most important conferences and journals. Although this research 
is descriptive in nature, it uses quantitative analysis to identify groups of closely connected articles.

A project of this sort implies a reversal of the usual conception of the variety of knowledge. It is neither a problem to be solved, nor objective evidence of cognitive vitality, but rather an object of empirical study. This variety of knowledge is the result of concrete research practices and it is precisely the empirical study of these practices that must be brought to light. It is thus a matter of understanding what is at stake in the emergence of the variety of knowledge rather than either deploring or celebrating it. Ultimately, this paper seeks to contribute to a better understanding of the theoretical issues that animate, as Venkataraman puts it, the "invisible college" of entrepreneurship scholars (1997, p.120). Lievrouw (1990) suggests that the "invisible college" is an informal communication process and defines it as an informal affiliation of scientists with common interests who are already strongly embedded in other institutions and who might live some distance from one another.

This paper begins by discussing the results in previous entrepreneurship research. It then reviews the entrepreneurship literature, and compares it with the results. Next, it discusses the implications of the entrepreneurship research field. Finally, it presents the explanation of the methodological articulation of this study and its results.

\section{ENTREPRENEURSHIP RESEARCH AS AN OBJECT OF STUDY}

Along with entrepreneurship's quest for legitimacy among the disciplines of management, a number of scholars have considered the field's development as an object of study in its own right. Considering the fragmentation that seems to plague entrepreneurship, Aldrich and Baker (1997) remark that in young scientific fields, where there is little consensus on definitions or approaches, convergence is arrived at "because researchers are attracted by the initial progress made by early investigators." In this light, they suggest that "influence comes from exemplary research, not from the propagation of rules or admonitions" and conclude that "the field will be shaped by those who produce research that interests and attracts others to build on their work" (ALDRICH; BAKER, 1997, p. 398).

Many authors have published literature surveys and conceptual synthesis that categorize types of entrepreneurship scholarship based on assumed themes that may characterize the field (BUSENITZ et al., 2003; BYGRAVE; HOFER, 1991; DAVIDSSON; LOW; WRIGHE, 2001; GARTNER, 1985; LOW, 2001 ; LOW; MACMILLAN, 1988; SHANE; VENKATARAMAN, 2000; UCBASARAN; WESTHEAD; WRIGHT, 2001; WORTMAN, 1987; ZAHRA; DESS, 2001). From a more empirical standpoint, Déry and Toulouse (1996) analyzed coauthor relations to offer a detailed account of the social structuration of the field as evidenced by the Journal of Business Venturing between 1986 and 1993. The authors found MacMillan's work, although broad, emblematic of the analysis of problems in the evaluating of investment projects. Shane (1997) examined the impact that specific authors (and institutions) had on entrepreneurship research by counting the number of publications in 19 academic journals deemed to be of high-quality. Adjusting for co-authorship and a journal's standing, he found that MacMillan, Covin, Birley, Bygrave and himself, were the five scholars who impacted the most this field.

Closer to the idea that scholars build upon each other's work, a few studies look more closely at the references found in entrepreneurship articles. For instance, Ratnatunga and Romano (1997) analyzed the references in 725 articles from six journals associated with small enterprise research between 1986 and 1992. In the most cited articles in three publication periods (1975$80 ; 1981-85 ; 1986-1992)$, they found the personal characteristics of entrepreneurs to be the only consistent topic of research over that time. On the other hand, Chandler, G. N. and Lyon (2001) used a sample of 416 empirical articles published in entrepreneurship and management 
journals to systematically analyze some of the methodological trends characterizing the field. The authors show that the quality of the empirical research in entrepreneurship has improved, but that the reliability and validity issues remain relatively unsophisticated. In order to identify the most influential journals for entrepreneurship research, Fried (2003) identified 25 journals which were rated as "appropriate" or higher, including generalist and entrepreneurshipspecialized journals, academic and practitioner journals, and journals from multiple academic disciplines. In this study, the Journal of Business Venturing appears as the most important journal specialized in entrepreneurship.

More recently, Grégoire et al. (2006) analyzed the networks of co-citation emerging from 20,184 references listed in the 960 fulllength articles published in the Frontiers of Entrepreneurship Research series between 1981 and 2004. Their results provide evidence for the varying levels of convergence that have characterized entrepreneurship research over the years, as well as the evolution of the conceptual themes that have attracted scholars' attention in different periods. In this perspective, Cornelius, Landström and Persson (2006) showed through a bibliometric analysis of research articles cited between 1982 and 2004 that only three articles in their analysis reached the 100 citation threshold. Schildt, Zahra and Sillanpää (2006) analyzed co-citation patterns of entrepreneurshiprelated articles published in the years 2000 to 2004 and identified the 25 most central research streams in entrepreneurship. As Reader and Watkins (2006) suggest in their survey to explore the intellectual structure of entrepreneurship research by identifying groups of scholars whose work fall into similar areas, there seem to be many interpretations and labels that could be applied to specific connections and groups of authors.

In light of these observations, PereiraLaverde (2007) believes that representing the field of entrepreneurship in terms of scholarly communities is an integral element of the effort to understand the concrete practices of entrepreneurship research over time. It is therefore not a matter of establishing criteria to evaluate the scientific value or existing knowledge, designing research protocols to guarantee the scientific value of findings, or proposing avenues of research, study perspectives and paradigms capable of unifying the efforts of researchers in the field. It is, rather a matter of understand how the common competitive arena of entrepreneurship research is concretely structured by the social and collective interplay among members of the field and participating institutions (GARTNER; DAVIDSSON; ZAHRA, 2006).

\section{OBJECT OF STUDY AND METHOD OF RESEARCH}

This research was completed in two phases. The purpose of the first phase, called "macroanalysis" here, was to obtain an overview of the structuration of the field of entrepreneurship. This analysis had three stages. The first two activities were a review of the 1,112 full-length papers published in the Babson/Kauffman Conference's Frontiers of Entrepreneurship Research Proceedings between 1981 and 2009.

Five observations support the choice of this particular series as a representative sample of entrepreneurship research. First, the Conference is generally seen as the most important forum for entrepreneurship research, compared to other forums like Research in Entrepreneurship and Small Business (RENT), Entrepreneurship, Innovation and Small Business Network (ESBS/ EISB), and Institute for Small Business Affairs/ Institute for Small Business and Entrepreneurship (ISBA/ISBE) series (ALDRICH; BAKER, 1997; GRÉGOIRE et al., 2006). Second, the series is arguably representative of the entrepreneurship research presented in other academic journals (ALDRICH; BAKER, 1997). Third, the Conference presents a somewhat more global picture of the field than individual journals. And fourth, the Conference's 29-year record offers a comprehensive picture of the evolution of various research streams. 
In the first stage the papers published by the Babson/Kauffman Conference between the years 1981 to 2009 were grouped by topic in order to identify research streams within entrepreneurship and their relationships over time. This research used the Babson/Kauffman Conference's classification of topics, and this was supported by the approach of Schild, Zahra and Sillanpää (2006).

The second stage consisted of capturing the configuration of research streams. The Co-plot method (see also GILADY; SPECTOR; RAVEH, 1996; SEGEV; RAVEH; FARJOUN, 1999; WEBER; SHENKAR; RAVEH, 1996) is a novel technique to determine the similarity among research streams. Additionally, it revealed the structure of the correlation among the topics (major and minor) in each of the 1, 112 papers published by the Conference. Coplot is based on the integration of mapping concepts with a variant of regression analysis. It starts with a data matrix $\operatorname{Ynxp}$ of $n$ rows and $p$ columns; the rows are the $p$-variate observations (major topic) and the columns are the variables (minor topics).

The third stage in this phase was to identify journals that made up an acceptable forum for the exchange of entrepreneurship thought. Katz's article on the history of entrepreneurship education (2003), and Carraher and Paridon's article on the impact that journal rankings in entrepreneurship have on faculty pay (2008) were used as the first sources for journals to include. The list was completed by journals indexed by the independent publishers EBSCO, EconLit, Proquest, Springer, Sage, Emerald, Elsevier, Wiley, Oxford Journals, Taylor and Francis, Allied Academies, InderScience Publishers, World Scientific and The Directory of Open Access Journals.

Some journals related to the field of entrepreneurship were eliminated from this study due to a lack of information. These journals were: Entrepreneurship, Innovation and Change, Asian Journal of Business and Entrepreneurship, Journal of Small Business Finance, Entrepreneurship Development Review, and Journal of Applied African Business and Entrepreneurship.
The purpose of the second phase, called "microanalysis" here, was to obtain a more specific overview of the entrepreneurship research. The 378 articles published in the Journal of Business Venturing (JBV) between 2000 and 2010 were chosen as the object of study. This journal was chosen because it is clearly identified with entrepreneurship and is considered by influential members of the field to be one of the leading journals of entrepreneurship research (MACMILLAN, 1989, 1991, 1993; DÉRY; TOULOUSE, 1996; BUSENITZ et al., 2003; FRIED, 2003; CARRAHER; PARIDON, 2008). These 11-year records also offer a comprehensive and recent picture of the state of the art in the field of entrepreneurship.

This phase was accomplished in three stages. In the first, the 378 articles were grouped into research streams as identified by the Babson/ Kauffman Conference. This stage also elucidated the relative importance of the paradigms in the specific context of the JBV.

In the second stage, this research followed the approach of Déry and Toulouse (1996) to analyze the social content of the 378 articles of the JBV. The social content was revealed through an inventory of three sociological markers: the authors, the institutions with which they are affiliated, and the references cited in each article. This activity was used to construct an occurrence matrix.

In the third stage, the occurrence matrix was transformed into two co-occurrence matrices - one for the articles and the other for all the references in those articles. The first co-occurrence matrix shows classic co-author networks (MULLINS, 1973). The second co-occurrence matrix was used to analyze the references by studying co-citation. This co-occurrence matrix was based on scientometry's central hypothesis to show that there is no intellectual or instrumental relationship between each possible pair of titles cited as references (CAWKELL, 1976; GARFIELD, 1983). This co-occurrence matrix shows all the reference networks according to a threshold of citations and co-occurrences. These networks thus follow the hierarchy of the constituent element's citations frequency. 


\section{PRESENTATION OF RESULTS}

\section{I Macroanalysis}

This research revealed "groups" of similar topics. Each group reflects a distinct theme in entrepreneurship research, although many of the groups are related. The results show such labels as groups of topics that have more clearly defined boundaries as to which scholars/documents on which to focus. These groups are the research streams in the field of entrepreneurship. In 29 years, the Babson/Kauffman Conference published a total of 1,122 articles identified by 61 research topics and grouped in 20 research streams (table 1). These results show that the field of entrepreneurship is a transversal discipline, in which one phenomenon can be studied from different perspectives. Schild, Zahra and Sillanpää (2006) analyzed 733 articles from 30 journals with entrepreneurship-related content. A similar result was obtained in their study. These authors identified 25 scholarly communities because they segmented certain research streams. For example, they discuss value creation from corporate entrepreneurship, and corporate entrepreneurship and venturing.

Table 1 shows research streams that have been constant over time, such as Accounting/ Finance and Entrepreneurship, Psychology and Entrepreneurship, Strategy and Entrepreneurship, and others. Other research streams are intermittent or relatively new, such as Ethnicity and Entrepreneurship, Teams and Entrepreneurship, and Social and Entrepreneurship. This result is similar to that of Grégoire et al. (2006) about the study of convergence in entrepreneurship research. These authors found that scholars have repeatedly drawn from works emphasizing the identification and exploitation of opportunities, the antecedents and consequences of innovation and entrepreneurship firm-level orientation/ behaviors, the issues and dynamics surrounding new venture emergence, survival and growth, the factors and dynamics affecting new-venture performance, the individual characteristics of entrepreneurs, the practice of venture capitalists and the contribution they make to the firms they finance, and the influence of social networks in entrepreneurship.

Sixty-five percent of the articles published by the Babson/Kauffman Conference are represented by the research streams of Accounting/ Finance and Entrepreneurship, Psychology and Entrepreneurship, New Business and Entrepreneurship, Strategy and Entrepreneurship, and Corporate and Entrepreneurship. The most representative topics were Venture capital, Personal characteristics, Start-ups, Strategy and Corporate venturing, representing approximately $36 \%$.

Although the results show different research topics, one study can include multiple topics. Thus one article can have one major topic and one or two minor topics. For example, one study of university spin-offs as a mechanism of technology transfer (major topic) can implicate the subjects of entrepreneurial process and incubators (minor topics). In Figure 1, the 20 streams of research previously identified are located in two-dimensional "major and minor topics space." Based on Figure 1, there is a basic grouping in research streams. This basic structure can be crystallized into the following seven groups:

a) group 1. Technology, New business and Government

b) group 2. Accounting/Finance, Economics and Franchising

c) group 3. Theory and Education

d) group 4. Psychology, Cognition and Women

e) group 5. Strategy, Corporate, International, Family firms and Failure

f) group 6. Ethnic and Social

g) group 7. Sociology and Teams

These seven groups show the most common combinations in research streams of entrepreneurship among the 1,122 articles published by the Babson/Kauffman Conference from 1989 to 2009 . The coefficient of alienation $(0.25)$ is relatively low. This means that although seven clusters of research streams can be identified, they are dispersed. In spite of this, the results give some idea of the intellectual structure of 
Table 1 - Research streams in entrepreneurship: FER 1981-2009.

\begin{tabular}{|c|c|c|c|c|c|c|c|c|c|c|c|c|}
\hline \multirow{2}{*}{ Field } & \multirow{2}{*}{ Research streams } & \multirow{2}{*}{ Topics } & \multicolumn{6}{|c|}{ Period } & \multirow{2}{*}{$\begin{array}{l}\text { Total by } \\
\text { topic }\end{array}$} & \multirow{2}{*}{$\begin{array}{l}\text { Incidence } \\
\text { by topic }\end{array}$} & \multirow{2}{*}{$\begin{array}{l}\text { Total by } \\
\text { subfield }\end{array}$} & \multirow{2}{*}{$\begin{array}{r}\text { Incidence } \\
\text { by subfielc }\end{array}$} \\
\hline & & & 1981-1985 & 1986-1990 & 1991-1995 & $1996-2000$ & 2001-2005 & 2006-2009 & & & & \\
\hline \multirow{62}{*}{ 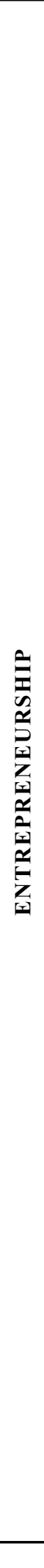 } & \multirow{6}{*}{$\begin{array}{ll} & \text { Accounting/Finance } \\
1 & \text { and } \\
\text { Entrepreneurship }\end{array}$} & $1 \quad$ Venture capital & 39 & 13 & 20 & 12 & 25 & 10 & 119 & $10.7 \%$ & \multirow{6}{*}{196} & \\
\hline & & $2 \quad$ Start-Ups financing & & 9 & 1 & 18 & & & 28 & $2.5 \%$ & & \\
\hline & & 3 Financing & & & 11 & 4 & & 7 & 22 & $2.0 \%$ & & $17.6 \%$ \\
\hline & & $4 \quad$ Business angels & & & 2 & 2 & 10 & 4 & 18 & $1.6 \%$ & & \\
\hline & & $5 \quad$ Investment & & & & 7 & & & 7 & $0.6 \%$ & & \\
\hline & & 6 Equity & & & & 2 & & & 2 & $0.2 \%$ & & \\
\hline & & $7 \quad$ Personal characteristics & 13 & 11 & 13 & 23 & 3 & 19 & 82 & $7.4 \%$ & & \\
\hline & & $8 \quad$ Typologies & 14 & 21 & & & 13 & 2 & 50 & $4.5 \%$ & & \\
\hline & Psychology and & $9 \quad$ Managerial characteristics & & 8 & 4 & 2 & & & 14 & $1.3 \%$ & 176 & $158 \%$ \\
\hline & Entrepreneurship & 10 Background/ experiences & 9 & & & 4 & & & 13 & $1.2 \%$ & 170 & $15.0 \%$ \\
\hline & & 11 Leadership & & & & & 10 & & 10 & $0.9 \%$ & & \\
\hline & & 12 Owner-Manager & & 4 & 3 & & & & 7 & $0.6 \%$ & & \\
\hline & & 13 Start-Ups & 24 & 32 & 16 & 3 & 6 & & 81 & $7.3 \%$ & & \\
\hline & 3 Entrepreneurshin & 14 New ventures & & 2 & 1 & 31 & 1 & & 35 & $3.1 \%$ & 123 & $11.1 \%$ \\
\hline & & 15 Entrepreneurial process & & & 7 & & & & 7 & $0.6 \%$ & & \\
\hline & & 16 Strategy & 3 & 10 & 7 & 18 & 10 & 13 & 61 & $5.5 \%$ & & \\
\hline & & 17 Growth & & & 11 & 21 & 5 & & 37 & $3.3 \%$ & & \\
\hline & 4 Entrepreneurship & 18 Resources & & & & 2 & 9 & & 11 & $1.0 \%$ & 122 & $11.0 \%$ \\
\hline & & 19 Alliances & & & 4 & 6 & 1 & & 11 & $1.0 \%$ & & \\
\hline & & 20 Entrepreneurial orientation & & & & & 2 & & 2 & $0.2 \%$ & & \\
\hline & & 21 Corporate venturing & 8 & 9 & 7 & 5 & 18 & 13 & 60 & $5.4 \%$ & & \\
\hline & & 22 Entrepreneurial management & & 9 & 6 & 4 & & & 19 & $1.7 \%$ & & \\
\hline & 5 Entrepreneurship & 23 Organization & & & 5 & & & 13 & 18 & $1.6 \%$ & 106 & $9.5 \%$ \\
\hline & & 24 Intrapreneurs & 2 & 3 & & & & & 5 & $0.4 \%$ & & \\
\hline & & 25 Human resources & & & & 2 & 2 & & 4 & $0.4 \%$ & & \\
\hline & & 26 Technology based firms & 3 & 15 & 9 & 1 & 4 & & 32 & $2.9 \%$ & & \\
\hline & 6 Technology and & 27 University related studies & 9 & 2 & 4 & & 1 & & 16 & $1.4 \%$ & 66 & $5.9 \%$ \\
\hline & Entrepreneurship & 28 Technological innovation & & & 10 & 2 & & & 12 & $1.1 \%$ & 00 & 年 \\
\hline & & 29 Technology commercialization & & & & & 6 & & 6 & $0.5 \%$ & & \\
\hline & & 30 Opportunity identification & & 1 & 3 & 5 & 22 & 3 & 34 & $3.1 \%$ & & \\
\hline & 7 Cognition and & 32 Cognitive process & & & 1 & & 4 & 15 & 20 & $1.8 \%$ & 59 & $53 \%$ \\
\hline & Entrepreneurship & 31 Creative business ideas & & & & 3 & & & 3 & $0.3 \%$ & (1) & $5.5 /$ \\
\hline & & 33 Learning / Knowledge & & & & & & 2 & 2 & $0.2 \%$ & & \\
\hline & & 34 Country studies & 11 & 11 & 6 & 1 & 7 & & 36 & $3.2 \%$ & & \\
\hline & 8 Entrepreneurship & 35 Industry & & 1 & 1 & 1 & 1 & 4 & 8 & $0.7 \%$ & 51 & $4.6 \%$ \\
\hline & & 36 Environment & & 3 & & & & 4 & 7 & $0.6 \%$ & & \\
\hline & & 37 Education / Training & 5 & 1 & 5 & & 2 & 1 & 14 & $1.3 \%$ & & \\
\hline & 9 Entrepreneurship & 38 Education / Careers & 8 & 4 & & & & & 12 & $1.1 \%$ & 31 & $2.8 \%$ \\
\hline & & 39 Education / Methodology & & 2 & 3 & & & & 5 & $0.4 \%$ & & \\
\hline & & 40 Public policy & 10 & & 2 & & & 2 & 14 & $1.3 \%$ & & \\
\hline & 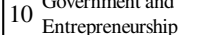 & 41 Incubators & 4 & 6 & 2 & & & & 12 & $1.1 \%$ & 29 & $2.6 \%$ \\
\hline & & 42 Assistance programs & & & & 2 & 1 & & 3 & $0.3 \%$ & & \\
\hline & $11^{\text {Sociology and }}$ & 43 Social networks & & & 1 & 5 & 7 & 6 & 19 & $1.7 \%$ & 28 & $25 \%$ \\
\hline & Entrepreneurship & 44 Alliances/Partnerships & & 2 & 7 & & & & 9 & $0.8 \%$ & 20 & 2.070 \\
\hline & & 45 International venture development & 5 & & & & 4 & 11 & 20 & $1.8 \%$ & & \\
\hline & 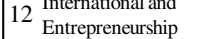 & 46 Global entrepreneurs & & & 4 & & & & 4 & $0.4 \%$ & 26 & $2.3 \%$ \\
\hline & & 47 Geographic expansion & & & & 2 & & & 2 & $0.2 \%$ & & \\
\hline & 13 Women and & 48 Women entrepreneurs & 6 & 5 & 2 & 2 & 3 & 2 & 20 & $1.8 \%$ & 23 & $21 \%$ \\
\hline & Entrepreneurship & 49 Minority entrepreneurs & & & & & 2 & 1 & 3 & $0.3 \%$ & 23 & \\
\hline & 14 Theory and & 50 Techniques / Methods & 2 & 1 & 3 & & 3 & 4 & 13 & $1.2 \%$ & 20 & $18 \%$ \\
\hline & Entrepreneurship & 51 Theorizing about entrepreneurship & 7 & & & & & & 7 & $0.6 \%$ & 20 & 1.07 \\
\hline & & 52 Societal contributions & & & 4 & & 1 & 4 & 9 & $0.8 \%$ & & \\
\hline & 15 Social and & 53 Not-For-Profit sector & & & & 4 & & & 4 & $0.4 \%$ & 14 & $1.3 \%$ \\
\hline & & 54 Social responsability & & & & 1 & & & 1 & $0.1 \%$ & & \\
\hline & $16 \begin{array}{l}\text { Family firms and } \\
\text { Entrepreneurship }\end{array}$ & 55 Family firms & & & & & 7 & 6 & 13 & $1.2 \%$ & 13 & $1.2 \%$ \\
\hline & 17 Failure and & 56 Survival & & & 2 & & 5 & 1 & 8 & $0.7 \%$ & 12 & $11 \%$ \\
\hline & Entrepreneurship & 57 Failure / Exit & & & 2 & & 2 & & 4 & $0.4 \%$ & 12 & $1.1 \%$ \\
\hline & $18 \begin{array}{l}\text { Teams and } \\
\text { Entrepreneurship }\end{array}$ & 58 Teams characteristics & & & & & 1 & 7 & 8 & $0.7 \%$ & 8 & $0.7 \%$ \\
\hline & $\begin{array}{l}19 \begin{array}{l}\text { Franchising and } \\
\text { Entrepreneurship }\end{array} \\
\end{array}$ & 59 Franchising & & & 2 & 4 & & & 6 & $0.5 \%$ & 6 & $0.5 \%$ \\
\hline & Ethnic and & 60 Culture / Inmigrants & & & & & 2 & & 2 & $0.2 \%$ & 3 & $0.3 \%$ \\
\hline & Entrepreneurship & 61 Ethnic / Minority Entrepreneurs & & & & 1 & & & 1 & $0.1 \%$ & & \\
\hline & & Total & 182 & 185 & 191 & 200 & 200 & 154 & 1,112 & $100 \%$ & 1,112 & $100 \%$ \\
\hline
\end{tabular}

Source: authors. 


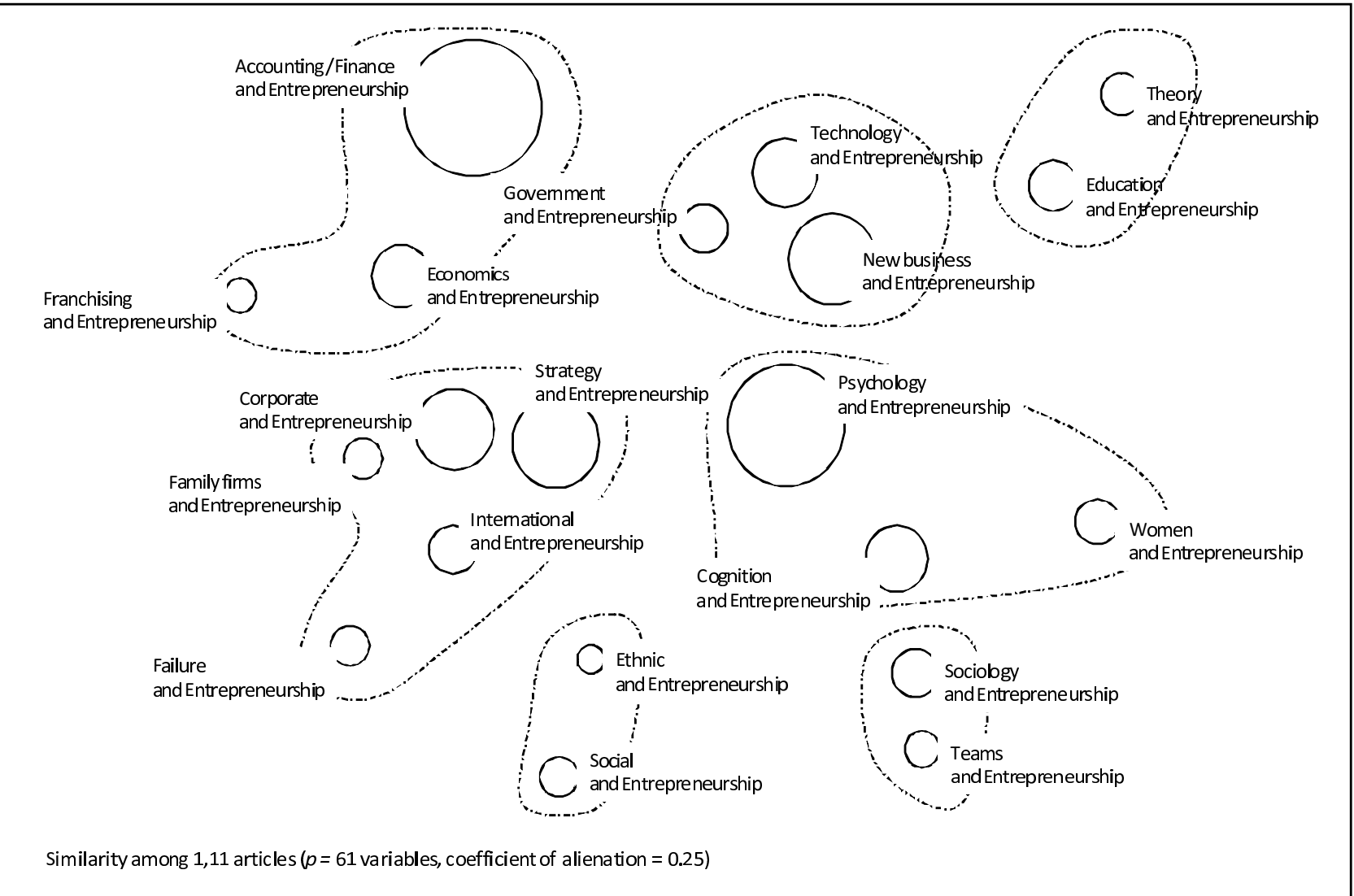

Figure 1 - Intellectual structure of entrepreneurship research: FER 1981-2009.

Source: authors.

entrepreneurship research. These clusters are consistent with clusters found by Ratnatunga and Romano (1997), Reader and Watkins (2006), and Schildt, Zahra and Sillanpää (2006), who all used different techniques and databases. As such, this observation suggests that while they are drawn from a single publication outlet, our observations are generally representative of the field as a whole.

Finally, this study identified 49 specialized journals focused on entrepreneurship. Approximately $63 \%$ of the journals are published in the United States and the United Kingdom (table 2). New Zealand, Singapore, Holland and Saudi Arabia represent approximately $20 \%$.

Although these 49 specialized journals are focused on entrepreneurship, some have a general approach in the field of entrepreneurship. Journals like Entrepreneurship Theory and Practice, Journal of Business Venturing, Journal of Enterprising Culture, International Review of Entrepreneurship, among others, are examples of this approach.
Other journals emphasize a specific topic in the discipline. Some examples of this group are Journal of Small Business and Entrepreneurship, Entrepreneurship and Regional Development, Journal of Entrepreneurship Education and Strategic Entrepreneurship Journal.

\subsection{Micro analysis}

The 378 articles published by JBV were organized according to the classification in Table 1. Similar to the results in Table 1, Figure 2 shows that the research stream of Accounting/Finance and Entrepreneurship was the most representative with $14.8 \%$ of incidence in the period 2000 to 2010 in JBV. The research streams of Psychology and Entrepreneurship, Strategy and Entrepreneurship, and Corporate and Entrepreneurship were also commonly represented in the JBV during this period. 
Table 2 - Entrepreneurship journals.

\begin{tabular}{|c|c|c|c|}
\hline & Journal & Country & Year \\
\hline 1 & Journal of Small Business Management & United States & 1972 \\
\hline 2 & International Small Business Journal & United Kingdom & 1982 \\
\hline 3 & Journal of Small Business and Entrepreneurship & Canada & 1983 \\
\hline 4 & Journal of Business Venturing & United States & 1985 \\
\hline 5 & Entrepreneurship Theory and Practice & United States & \multirow{2}{*}{1988} \\
\hline 6 & Family Business Review & United States & \\
\hline 7 & Entrepreneurship and Regional Development & United Kingdom & \multirow{3}{*}{1989} \\
\hline 8 & Journal of Business and Entrepreneurhsip & United States & \\
\hline 9 & Small Business Economics & Holland & \\
\hline 10 & Journal of Entrepreneurship & India & 1992 \\
\hline 11 & Journal of Enterprising Culture & Singapore & 1993 \\
\hline 12 & Journal of Small Business and Enterprise Development & United Kingdom & 1994 \\
\hline 13 & International Journal of Entrepreneurial Behaviour and Research & United Kingdom & \multirow{2}{*}{1995} \\
\hline 14 & Journal of Small Business Strategy & United States & \\
\hline 15 & Journal of Developmental Entrepreneurship & Singapore & \multirow{2}{*}{1996} \\
\hline 16 & Journal of Entrepreneurial and Small Business Finance & United Kingdom & \\
\hline 17 & New England Journal of Entrepreneurhsip & United States & 1998 \\
\hline 18 & Venture Capital & United States & 1999 \\
\hline 19 & International Journal of Entrepreneurship & United States & \multirow{2}{*}{2000} \\
\hline 20 & International Journal of Entrepreneurship and Innovation & United Kingdom & \\
\hline 21 & International Journal of Entrepreneurship and Innovation Management & United Kingdom & \multirow{3}{*}{2001} \\
\hline 22 & Journal of Applied Management and Entrepreneurship & United States & \\
\hline 23 & Journal of Entrepreneurial Finance and Business Ventures & United Kingdom & \\
\hline 24 & Journal of Entrepreneurship Education & United States & 2002 \\
\hline 25 & International Review of Entrepreneurship & Ireland & \multirow{3}{*}{2003} \\
\hline 26 & Journal for International Business and Entrepreneurship Development & Saudi Arabia & \\
\hline 27 & Journal of International Entrepreneurship & Holland & \\
\hline 28 & International Journal of Entrepreneurship and Small Business & New Zealand & \multirow{2}{*}{2004} \\
\hline 29 & International Journal of Globalisation and Small Business & Germany & \\
\hline 30 & International Indigenous Journal of Entrepreneurship Advancement, Strategy and Education & New Zealand & \multirow{7}{*}{2005} \\
\hline 31 & International Entrepreneurship and Management Journal & United States & \\
\hline 32 & Academy of Entrepreneurship Journal & United States & \\
\hline 33 & Foundations and Trends in Entrepreneurship & United States & \\
\hline 34 & Entrepreneurial Executive & United States & \\
\hline 35 & Journal of Asia Entrepreneurship and Sustainability & New Zealand & \\
\hline 36 & World Review of Entrepreneurship, Management and Sustainable Development & United Kingdom & \\
\hline 37 & Business Journal for Entrepreneurs Quarterly & United States & \multirow{2}{*}{2006} \\
\hline 38 & Journal of International Business and Entrepreneurship & Saudi Arabia & \\
\hline 39 & International Journal of Technoentrepreneurship & Singapore & \multirow{2}{*}{2007} \\
\hline 40 & Strategic Entrepreneurship Journal & United Kingdom & \\
\hline 41 & Southern Journal of Entrepreneurship & United States & 2008 \\
\hline 42 & International Journal of Entrepreneurial Venturing & United Kingdom & \multirow{4}{*}{2009} \\
\hline 43 & International Journal of Gender and Entrepreneurship & United Kingdom & \\
\hline 44 & Journal of Chinese Entrepreneurship & China & \\
\hline 45 & Journal of Women's Entrepreneurship and Education & Serbia & \\
\hline 46 & Journal of Global Entrepreneurship Research & Iran & \multirow{4}{*}{2010} \\
\hline 47 & Journal of Social Entrepreneurship & United Kingdom & \\
\hline 48 & Annals of Innovation and Entrepreneurship & Sweden & \\
\hline 49 & International Journal of Social Entrepreneurship and Innovation & United Kingdom & \\
\hline
\end{tabular}

Source: authors. 


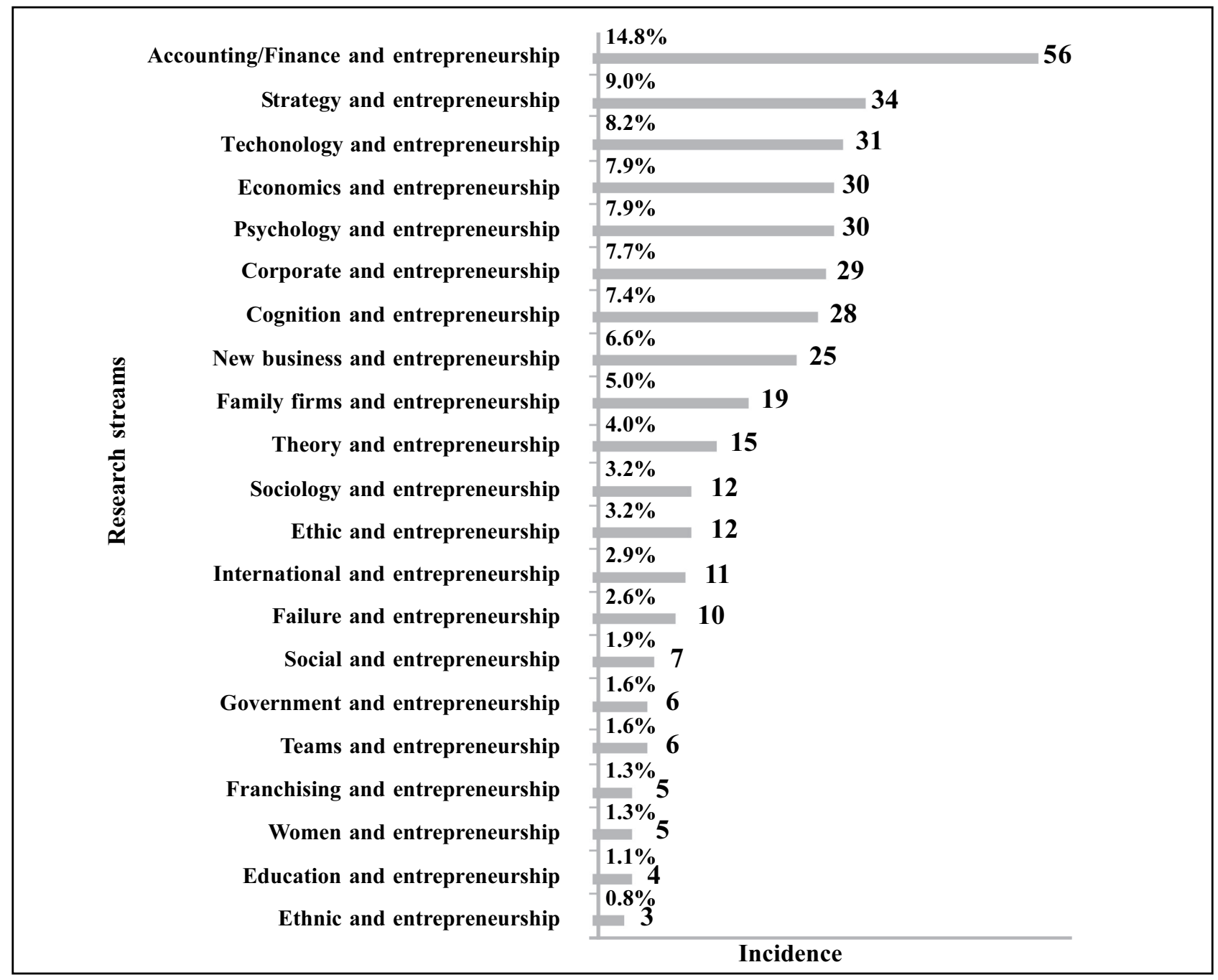

Figure 2 - Incidence of research streams in entrepreneurship: JBV 2000-2010.

Source: authors.

In contradistinction to the analysis and results of the 1,122 articles published by the Babson/Kauffman Conference, a new research stream was identified in the JBV: Ethics and Entrepreneurship. This research stream emphasizes business ethics as the main topic. However, the development of Social and Entrepreneurship as a sustained group is related to ethics in business.

Over eleven years, the JBV published a total of 378 articles by 604 different authors, 136 of whom contributed to more than one article (table 3). Through these authors, a total of 319 institutions (almost all universities) have taken part in constructing the field of entrepreneurship research. Of this number, only $35.7 \%$ appeared more than once in the corpus. The articles published in the JBV contain 16,389 different references, the vast majority of which appeared only once. These 16,389 titles were written by 11,413 different authors, the majority of whom were cited only once. In a similar study, Déry and Toulouse’s (1996) reveal the field of entrepreneurship to be a social and collective construction characterized by social fragmentation, a collective game of struggles, strategic alliances, and disciplinary introversion.

Analysis of the 287 groups of authors in the corpus shows the network of co-author relations among researchers publishing in the JBV (see Figure 3). Largely dominated by its editor-inchief, Dean A. Shepherd, whose name appears as co-author for 25 of the 378 articles in the corpus, the JBV's network of co-author relations is an 
Table 3 - General portrait of the corpus: JBV 2000-2010.

\begin{tabular}{lccccc}
\hline & $\mathbf{5}$ & $\begin{array}{c}\text { Frequency } \\
\mathbf{\%}\end{array}$ & $\mathbf{2 2}$ & $\mathbf{\%}$ & Total \\
\hline $\begin{array}{l}\text { Author } \\
\quad \text { Occurrence }\end{array}$ & 468 & $77.5 \%$ & 136 & $22.5 \%$ & 604 \\
$\quad$ Numer/Text & 91 & $24.1 \%$ & 287 & $75.9 \%$ & 378 \\
& & & & $35.7 \%$ & 319 \\
Institution & 205 & $64.3 \%$ & 114 & & \\
Reference & & & & 16389 \\
$\quad$ Title & 11734 & $71.6 \%$ & 4655 & $28.4 \%$ & 11413 \\
$\quad$ Author & 7635 & $66.9 \%$ & 3778 & $33.1 \%$ & \\
\hline
\end{tabular}

Source: authors.

intricate web of authors from a multiplicity of loosely connected sub-networks. Four subnetworks headed by Moren Lévesque, Robert A. Baron, Andrew L. Zacharakis and Johan Wiklund emerge from Shepherd in the global network. Furthermore, the network organized around Shepherd consists of eight unrelated sub-networks.

The architecture of the network suggests that co-author relations depend mainly on research problematic. For example, the subnetworks dominated by Shepherd are aligned with problems of venture capital, strategy, cognition, corporate, psychology and new venture. Nevertheless, the network shows a sub-network dominated by Shaker A. Zahra around topics like strategy, corporate, international and technology.

With regard to the most frequently cited texts in the corpus and the co-citation linking them (Figure 4), the field of entrepreneurship, as used by the authors publishing in JBV, takes the form of a network organized around Shane and Venkataraman's (2000) conceptual statement about the "distinctive domain of entrepreneurship research." Within the Shane and Venkataraman umbrella there is a network around, Venkataraman (1997), Shane (2000), Schumpeter (1934) and Kirzner (1973). The focus of this cluster appears to be on entrepreneurial alertness and the perception of opportunities.

Just below this first cluster, there is a tight cluster of classics associated with the resourcebased view (BARNEY, 1991; PENROSE, 1959;
WERNERFELT, 1984). The high citation frequency of these works indicates that the resource-based view has continued to draw scholarly attention during the 2000-2010 period in the field of entrepreneurship. On the other hand, there is a continuous interest in the JBV in venture capital research. For instance, Sapienza's (1992) work on the contribution of venture capital is the most cited. Finally, a tightly knit cluster of works focused on the firm-level articulations of entrepreneurship. The works of Covin and Slevin (1991) and Lumpkin and Dess (1996) indicate that the research streams exploring the firm-level dimensions of entrepreneurship has grown in both extent and depth.

However, overall, the levels of convergence observed in this study are relatively low. For instance, Figure 4 shows that the most frequently cited reference over the entire 2000-2010 period (SHANE; VENKATARAMAN, 2000) is found in only 33 of the 378 articles studied - or $8.7 \%$ of the corpus. Similarly, only 6 references are cited between 18 and 24 times (i.e., 4.7\%-6.3\% of the corpus). Comparable levels of citation frequencies can also be observed in Grégoire et al. (2006), where the most cited works are found in no more than $5 \%$ to $6 \%$ of the relevant articles. By comparison, the most frequently cited works in the Strategic Management Journal over the 19801993 period (i.e., CHANDLER, A. D., 1962; PORTER, 1980; RUMELT, 1974) appeared in $31.9 \%, 23.9 \%$, and $18.1 \%$ of the journal's 599 


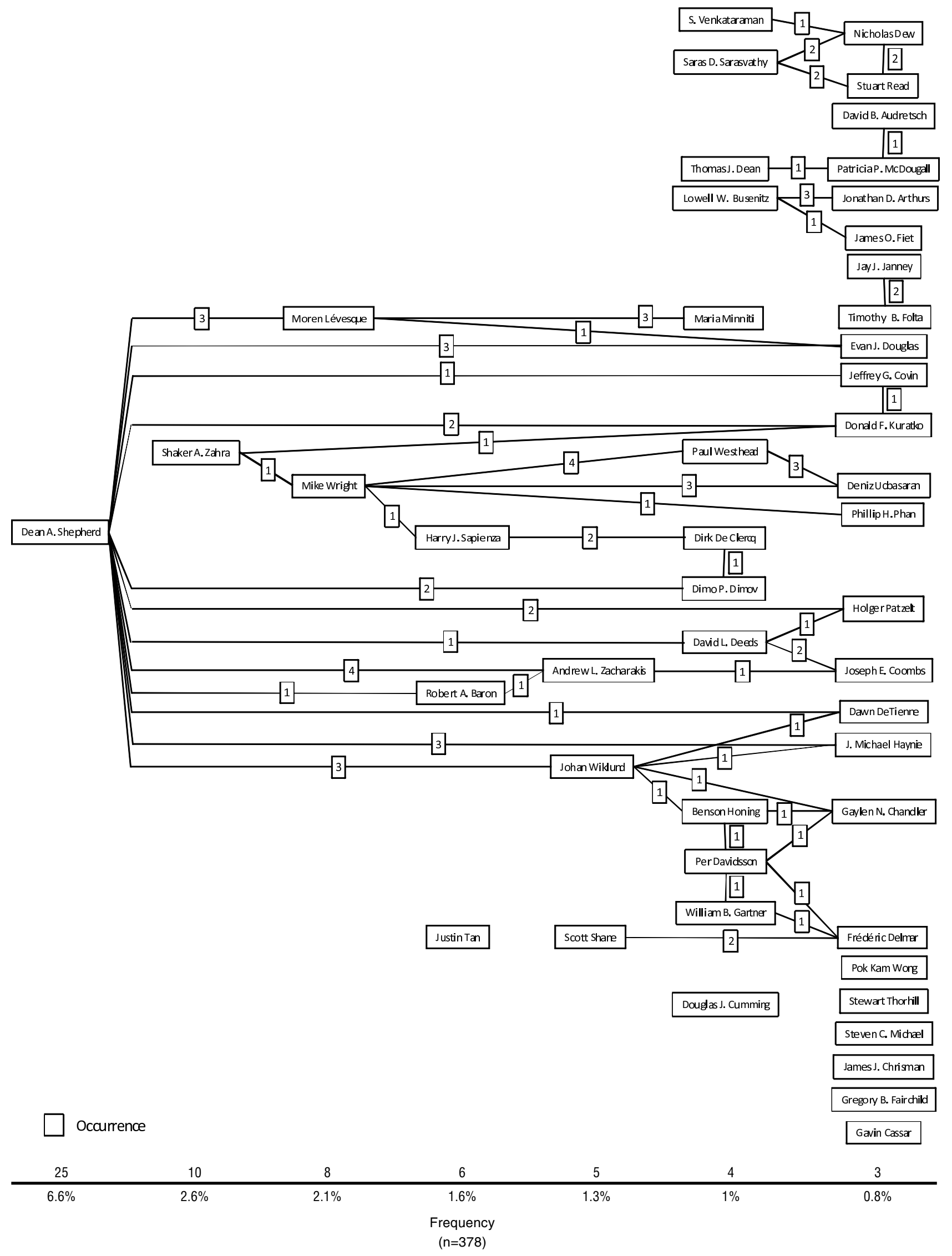

Figure 3 - Network of co-author relations: JBV 2000-2010.

Source: authors. 


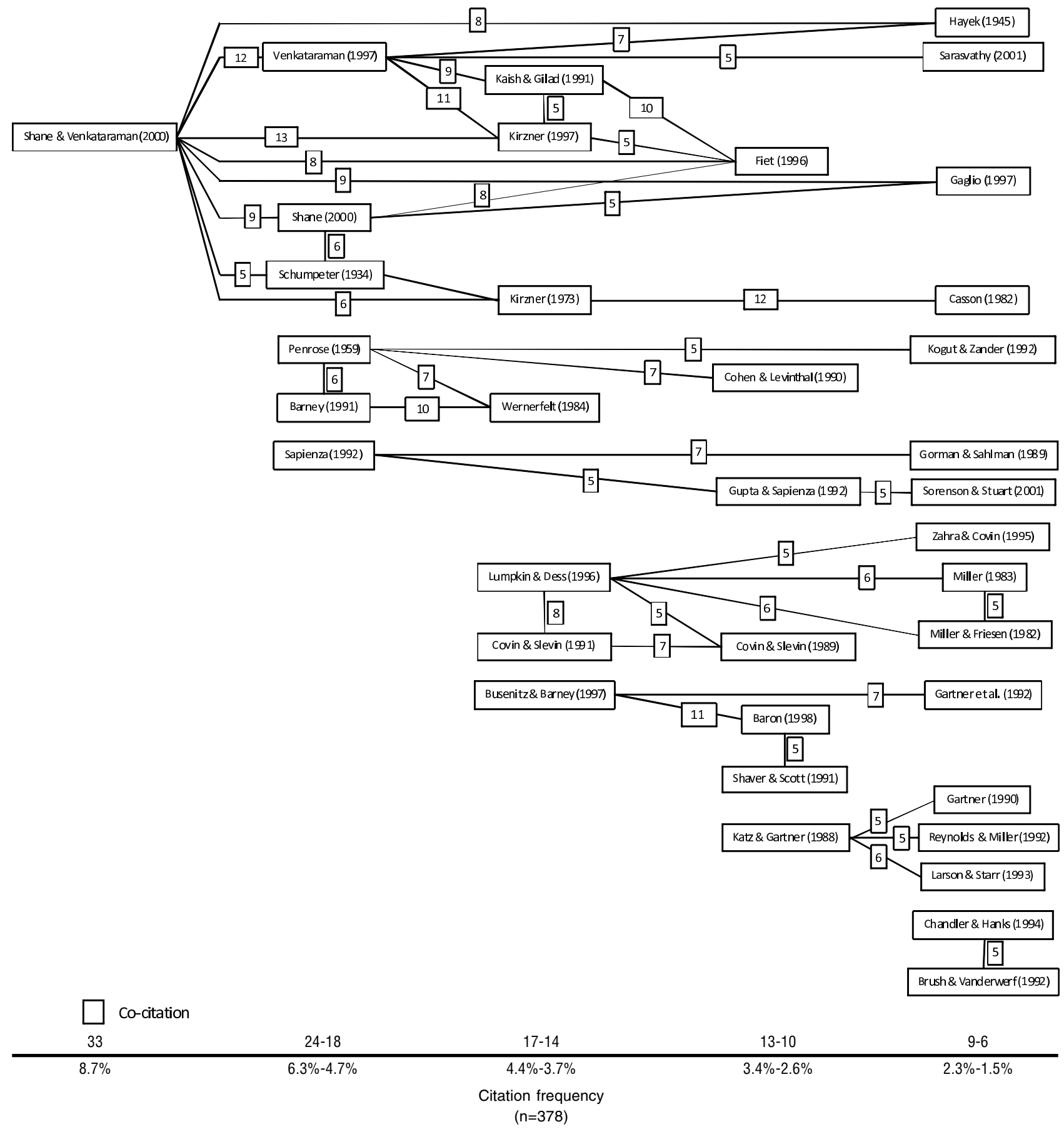

Figure 4- Network of citation and co-citation: JBV 2000-2010.

Source: authors.

articles for the period (DÉRY, 1997a, 1997b), respectively. As a further point of comparison, an earlier study noted that the most cited titles in the Journal of Business Venturing between 1986 and 1993 - MacMillan, Siegel and Subba Narasimha (1985) and Porter (1980) - were found in 13.1\% of the articles (DÉRY; TOULOUSE, 1996).

\section{LIMITATIONS AND AVENUES OF FUTURE RESEARCH}

Naturally, the evidence presented above is bound by its reliance on two sources of articles articles published in FER and JBV. While this study showed these sources to be pertinent and 
observed that the overall results were consistent with others, the validity of the findings would be increased if conducted systematic comparisons with other sources of entrepreneurship articles, for instance by focusing on entrepreneurshipspecific journals (e.g., CHANDLER; LYON, 2001; RATNATUNGA; ROMANO, 1997), and/or on entrepreneurship articles published in management journals (e.g., BUSENITZ et al., 2003; IRELAND; REUTZEL; WEBB, 2005). By extension, investigating the various forces that drive progress in each field would demand tan approach that goes beyond the analysis of the most-cited works and co-occurrence: to this end, other techniques to consider relationships between authors (e.g., READER; WATKINS, 2006), institutions (e.g., DÉRY; TOULOUSE, 1996), or the use of particular concepts, approaches, and variables with particular methods could be used (e.g., GRÉGOIRE; MEYER; DE CASTRO, 2002). Further insights could also be gained through systematic comparisons with other disciplines, with notably neighboring fields such as organizational behavior (e.g., CULNAN; O'REILLEY; CHATMAN, 1990), organization theory (e.g., ALDRICH et al., 1994), or strategic management (e.g., RAMOS-RODRIGUEZ; RUÍZ-NAVARRO, 2004). Ultimately, such studies would promote an explicit understanding of the nature and grounds of knowledge in entrepreneurship research, amounting to the field's distinctive epistemology.

\section{CONCLUSION}

The result of this research provides a revealing window into scholarly work. Based on the rich panorama opened by our data, many stories can be told: stories of scientific advance, overlooked opportunities, alternate viewpoints, or perhaps the politics within the academy. Given the widely acknowledged diversity of the entrepreneurship field, alternate stories are bound to be of interest to different audiences. Clearly, our results are open to many alternate interpretations and we invite the readers to make sense of them from their own perspectives. Our hope is that this article provides material that readers will find easy, enjoyable, and useful in interpreting key themes of contemporary entrepreneurship research.

Our analyses reveal four key qualities about research in entrepreneurship. First, this research remains highly fragmented, perhaps reflecting the "pre-paradigmatic" stage of the field (ZAHRA, 2005). Second, research findings appear to be noncumulative, evidenced by the limited citations of prior published works in the areas canvassed in our analyses. Third, Shane and Venkataraman's (2000) conceptual statement about the "distinctive domain of entrepreneurship research" is the most frequently cited work, and it is an entrepreneurshipspecific piece. Fourth, and finally, entrepreneurship researchers borrow heavily from their home disciplines and retain their academic loyalties to these disciplines.

The norms and values of a domain and the scholar's acceptance within that domain are affirmed by interaction with like-minded colleagues in the form of what Crane (1972) calls "invisible colleges." The manifestation of the visible or invisible college of entrepreneurship scholars will be whatever individuals who can "get published" and cite others, make it. Interestingly, our results suggest that if communities of scholars already agree on particular concepts and approaches (and share consistent sets of references), an important challenge remains in articulating the relationships between these concepts and approaches. This may demand that entrepreneurship scholars position their work in line with, against, or as a complement to those of different research communities.

It would be difficult, then, to come up with an overarching theme that could easily encompass the specific issues of these distinct groups of scholars and serve as label for what entrepreneurship, as an overall topic, represents (GARTNER, 2001). Convergence, then, in terms of developing a community of entrepreneurship scholars, seems to be more about the development of communities of scholars that share similar interest in specific topics in the entrepreneurship area. These observations would support critics who see entrepreneurship as a set of loosely connected research groups that lack an organizing framework 
or a dominant paradigm (ZAHRA; DESS, 2001). To be sure, having diverse themes in a field is not unusual. What is unusual is to uncover such disconnectedness among these groups (SCHILDT; ZAHRA; SILLANPÄÄ, 2006). As pointed out by Reader and Watkins (2006), the separations are not always just a matter of topic of interest but sometimes reflect cultural origin as well. Yet, this does not imply that entrepreneurship is condemned to remain a "hodgepodge" (SHANE; VENKATARAMAN, 2000) or "potpourri" (LOW, 2001) of research streams with little in common. Our evidence suggests that if the field advances, it is through the work of scholars who succeed in drawing the attention of others around some key ideas - echoing in that sense Aldrich and Baker's observations (1997).

By extension, the evidence in this research also points to the potential contribution that the field of entrepreneurship may ultimately make to the management sciences in particular, and to the social sciences in general. In this regard, it is notable that like other management areas, entrepreneurship research is not dominated by conceptual anchors from a single discipline. Entrepreneurship researchers need to talk to each other and, perhaps more important, connect their ideas and findings to mainstream disciplines. Opening this dialog can enrich future entrepreneurship research and increase its acceptance and academic legitimacy. Therefore, we hope that scholars in the field of entrepreneurship may look beyond their immediate cluster of interest to the many different themes/groups that comprise such a dynamic and growing community.

\section{REFERENCES}

ALDRICH, H. E.; BAKER, T. Blinded by the cites? has there been progress in the entrepreneurship field? In: SEXTON, D.; SMILOR, R. (Ed.). Entrepreneurship 2000. Chicago: Upstart Publishing Company, 1997. p. 377-400.

et al. Other people's concepts: why and how we sustain historical continuity in our field. Organization, London, v. 1, n. 1, p. 65-80, 1994.

BARNEY, J. Firm resources and sustained competitive advantage. Journal of Management, Thousand Oaks, v. 17, n. 1, p. 99-120, 1991.

BUSENITZ, L. W. et al. A. Entrepreneurship research in emergence: past trends and future directions. Journal of Management, Thousand Oaks, v. 29, n. 3, p. 285-308, 2003.

BYGRAVE, W. D.; HOFER, C. W. Theorizing about entrepreneurship. Entrepreneurship: theory and practice, Malden, v. 16, n. 2, p. 13-23, 1991.

CARRAHER, S. M.; PARIDON, T. J. Entrepreneurship journal rankings across the discipline. Journal of Small Business Strategy, Peoria, v. 19, n. 2, p. 89-98, 2008.

CAWKELL, A. E. Understanding science by analysing its literature. Essays of an Information Scientist, Middlesex, v. 2, p. 543-549, 1976.

CHANDLER, A. D. Jr. Strategy and structure. Cambridge, MA: MIT Press, 1962.

CHANDLER, G. N.; LYON, D. W. Issues of research design and construct measurement in entrepreneurship research: the past decade. Entrepreneurship: theory and practice, Malden, v. 25, n. 4, p. 101-113, 2001.

CORNELIUS, B.; LANDSTRÖM, H.; PERSSON, O. Entrepreneurial studies: the dynamic research front of a developing social science. Entrepreneurship: theory and practice, Malden, v. 30, n. 3, p. 375-398, 2006.

COVIN, J. G.; SLEVIN, D. P. A conceptual model of entrepreneurship as firm behavior. Entrepreneurship: theory and practice, Malden, v. 16, n. 1, p. 7-25, 1991.

CRANE, D. Invisible colleagues: diffusion of knowledge in scientific communities. Chicago: University of Chicago Press, 1972. 
CULNAN, M. J.; O’REILLEY, C. A.; CHATMAN, $\mathrm{J}$. A. Intellectual structure of research in organizational behavior, 1972-1984: a cocitation analysis. Journal of the American Society for Information Science, Washington, v. 41, n. 6, p. 453-458, 1990.

DAVIDSSON, P.; LOW, M. B.; WRIGHE, M. Editor's introduction: Low and MacMillan ten years on: achievements and future directions for entrepreneurship research. Entrepreneurship: theory and practice, v. 25, n. 4, p. 5-16, 2001.

DÉRY, R. La structuration socio-historique de la stratégie. In: NOËL, A. et al. (Ed.). Perspectives en management stratégique. Paris: Economica, 1997a. p. 15-63.

. Topographie du champ de recherche en stratégie d'entreprise. Management International, Montreal, v. 2, n. 1, p. 11-18. 1997b.

; TOULOUSE, J. M. Social structuration of the field of entrepreneurship: a case study. Canadian Journal of Administrative Sciences, Chichester, v. 13, n. 4, p. 285-305, 1996.

FRIED, V. H. Defining a forum for entrepreneurship scholars. Journal of Business Venturing, Amsterdam, v. 18, n. 1, p. 1-11, 2003.

GARFIELD, E. Citation data as science indicators. Essays of an Information Scientist, Philadelphia, v. 6 , p. 580, 1983.

GARTNER, W. B. A framework for describing and classifying the phenomenon of new venture creation. Academy of Management Review, Biarcliff Manor, v. 10, n. 4, p. 696-706, 1985.

. Is there an elephant in entrepreneurship research? blind assumptions in theory development. Entrepreneurship: theory and practice, Malden, v. 25, n. 4, p. 27-39, 2001.

DAVIDSSON, P.; ZAHRA, S. A. Are you talking to me? the nature of community in entrepreneurship scholarship. Entrepreneurship: theory and practice, Malden, v. 30, n. 3, p. 321331, 2006.

GILADY, R.; SPECTOR, Y.; RAVEH, A. Multidimensional scaling: an analysis of 1980-1990 computers. European Journal of Operations Research, [S. 1.], v. 95, n. 2, p. 439-450, Dec. 1996.

GRÉGOIRE, D. A.; MEYER, G. D.; DE CASTRO, J. O. The crystallization of entrepreneurship research DV's and methods in mainstream journals. In: BYGRAVE, W. D. et al. (Ed.). Frontiers of entrepreneurship research 2002: proceedings of the twenty-second annual entrepreneurship research conference. Boulder, Colorado: Center for Entrepreneurial Studies, Babson College, 2002. Disponível em: <http://fusionmx. babson.edu/entrep/fer/Babson2002/XXII/XXII/ XXII_P1.htm>. Acesso em: 06 dez. 2010

et al. Is there conceptual convergence in entrepreneurship research? a co-citation analysis of Frontiers of Entrepreneurship Research, 19812004. Entrepreneursip: theory and practice, Malden, v. 30, n. 3, p. 333-373, 2006.

IRELAND, R. D.; REUTZEL, C. R.; WEBB, J. W. Entrepreneurship research in AMJ: what has been published, and what might the future hold? Academy of Management Journal, New York, v. 48, n. 4, p. 556-564, 2005.

KATZ, J. A. The chronology and intellectual trajectory of American entrepreneurship education 1876-1999. Journal of Business Venturing, Amsterdam, v. 18. n. 2, p. 283-300, 2003.

KIRZNER, I. M. Competition and entrepreneurship. Chicago: University of Chicago Press, 1973.

LIEVROUW, L. A. Reconciling structure and process in the study of scholarly communication. In: BORGMAN, C. L. (Ed). Scholarly communication and bibliometrics. London: Sage Publications, 1990. p. 59-69. 
LOW, M. B. The adolescence of entrepreneurship research: Specification of purpose. Entrepreneurship: theory and practice, Malden, v. 25, n. 4, p. 17-25, 2001.

; MACMILLAN, I. C. Entrepreneurship: past research and future challenges. Journal of Management, Thousand Oaks, v. 14, n. 2, p. 139$161,1988$.

LUMPKIN, G. T.; DESS, G. G. Clarifying the entrepreneurial intention construct and linking it to performance. Academy of Management Review, Biarcliff Manor, v. 21, n. 1, p. 135-172, 1996.

MACMILLAN, I. C. Editor's note: delineating a forum for entrepreneurship scholars. Journal of Business Venturing, Amsterdam, v. 6, n. 2, p. 8387, 1991.

Editor's note: the emerging forum for entrepreneurship scholars. Journal of Business Venturing, Amsterdam, v. 8, n. 5, p. 377-381, 1993.

Editor's note: toward a forum for entrepreneurship scholars. Journal of Business Venturing, Amsterdam,v. 4, n. 5, p. 289-290, 1989.

; SIEGEL, R.; SUBBA NARASIMHA,

P. N. Criteria used by venture capitalists to evaluate new venture proposals. Journal of Business Venturing, Amsterdam, v. 1, n. 1, p. 119-128, 1985.

MULLINS, N. C. Theories and theory groups in contemporary American sociology. New York: Harper \& Row, 1973.

PENROSE, E. T. The theory of the growth of the firm. New York: John Wiley and Sons, 1959.

PEREIRA-LAVERDE, F. La evolución del espíritu empresarial como campo del conocimiento. Hacia una visión sistémica y humanista. Cuadernos de Administración, Bogotá, v. 20, n. 34, p. 11-37, 2007.
PORTER, M. E. Competitive strategy. New York: The Free Press, 1980.

RAMOS-RODRIGUEZ, A. R.; RUÍZNAVARRO, J. Changes in the intelectual structure of strategic management research: a bibliometric study of the strategic management journal, 1980-2000. Strategic Management Journal, Chichester,v. 25, n. 10, p. 981-1004, 2004.

RATNATUNGA, J.; ROMANO, C. A citation classics analysis of articles in contemporary small enterprise research. Journal of Business Venturing, Amsterdam, v. 12, n. 3, p. 197-212, 1997.

READER, D.; WATKINS, D. The social and collaborative nature of entrepreneurship scholarship: a co-citation and perceptual analysis. Entrepreneurship: theory and practice, Malden, v. 30, n. 3, p. 417-441, 2006.

RUMELT, R. P. Strategy, structure, and economic performance. Cambridge, MA: Harvard University Press, 1974.

SAPIENZA, H. J. When do venture capitalists add value? Journal of Business Venturing, Amsterdam, v. 7, n. 1, p. 9-27, 1992.

SCHILDT, H. A.; ZAHRA, S. A.; SILLANPÄÄ, A. Scholarly communities in entrepreneurship research: a co-citation analysis. Entrepreneurship: theory and practice, Malden, v. 30, n. 3, p. 399415, 2006.

SCHUMPETER, J. A. The theory of economics development. Cambridge, MA: Harvard University Press, 1934.

SEGEV, E.; RAVEH, A.; FARJOUN, M. Conceptual maps of the leading MBA programs in the United States: core courses, concentrations areas, and the ranking of the school. Strategic Management Journal, Chichester, v. 20, n. 6, p. 549-565, 1999.

R. bras. Gest. Neg., São Paulo, v. 14, n. 42, p. 41-58, jan./mar. 2012 
SHANE, S. Prior knowledge and the discovery of entrepreneurial opportunities. Organization Science, Linthicum, v. 11, n. 4, p. 448-469, 2000. Who is publishing the entrepreneurship research? Journal of Management, Thousand Oaks, v. 23, p. 1, p. 83-95, 1997.

; VENKATARAMAN, S. The promise of entrepreneurship as a field of research. Academy of Management Review, Biarcliff Manor, v. 25, n. 1, p. 217-226, 2000.

UCBASARAN, D.; WESTHEAD, P.; WRIGHT, $M$. The focus of entrepreneurial research: Contextual and process issues. Entrepreneurship: theory and practice, Malden, v. 25, n. 2, p. 57$80,2001$.

VENKATARAMAN, S. The distinctive domain of entrepreneurship research. In: KATZ, J. A. (Ed). Advances in entrepreneurship, firm emergence and growth. Oxford: JAI Press, 1997. p. 119-138.
WEBER, Y.; SHENKAR, O.; RAVEH, A. National versus corporate cultural fit in mergers and acquisitions: an exploratory study. Management Science, Linthicum, v. 42, n. 8, p. 1215-1227, 1996.

WERNERFELT, B. A resource-based view of the firm. Strategic Management Journal, Chichester, v. 5, n. 2, p. 171-180, 1984.

WORTMAN, M. S. Entrepreneurship: an integrating typology and evaluation of the empirical research in the field. Journal of Management, Thousand Oaks, v. 13, n. 2, p. 259-279, 1987.

ZAHRA, S. A. Disciplinary research and entrepreneurship scholarship. In: ALVAREZ, S. A.; AGARWAL, R.; SORENSON, O. (Ed.). Handbook of entrepreneurship research. $2^{\text {nd }} \mathrm{ed}$. New York: Kluwer, 2005. p. 253-258.

; DESS, G. G. Entrepreneurship as a field of research: encouraging dialogue and debate. Academy of Management Review, Biarcliff Manor, v. 26, n. 1, p. 8-10, 2001. 